\title{
Universal Preschool's Promise: Success in Early Childhood and Beyond
}

\author{
Jon Lasser • Kathleen Fite
}

Published online: 19 February 2011

(C) Springer Science+Business Media, LLC 2011

\begin{abstract}
Fueled by a belief that early intervention can prevent a host of educational woes, efforts to provide universal, publicly funded preschool have the potential to radically change the way we think about our commitments and responsibilities in education. We call for the implementation of innovative, universal preschool programs that attend to developmental characteristics of learners, cultural and linguistic diversity, ecosystemic context, and the new mandates on teacher training. Universal preschool has the potential to go far beyond mere "day-care," as it has the potential to establish the foundation for a lifelong love of learning and optimal social/emotional development. We also advocate for high-quality teacher training to populate preschools with high-quality teachers. If universal preschool is carefully planned and provided, K-12 education stands to benefit substantially.
\end{abstract}

Keywords Early childhood - Universal preschool · Diversity $\cdot$ Teacher training · Public policy

Though most agree that education reform is needed, there is little agreement about how to achieve success. Changes to the ways public education is financed, reductions to student-teacher ratios, and increased emphasis on

\section{J. Lasser $(\square)$}

Department CLAS, Texas State University-San Marcos, 601 University Drive, San Marcos, TX 78666, USA

e-mail: lasser@txstate.edu

\section{K. Fite}

Department of Curriculum and Instruction, Texas State University-San Marcos, 601 University Drive, San Marcos, TX 78666, USA

e-mail:kf02@txstate.edu standards-based approaches all have been suggested. We advance the proposal that universal preschool education (free preschool education available to all children) is the best approach to addressing the educational challenges of the twenty-first century.

Persuading policy makers that early childhood education is a good investment may be a tough sell, particularly in a poor economic climate. We contend that the provision of free preschool for all children makes economic sense when placed in the context of long-term academic and employment success. What happens to American children in education after early childhood? The data are not encouraging. Our students in math and science are ranked 48 out of 133 countries (Simmons 2011). Though this finger pointing provides little in terms of solutions, it raises questions about responsibilities and the origins of academic success. Promoting universal preschool as a means to improving academic and developmental outcomes for all children makes sense in both academic and economic contexts.

An investment in universal early childhood education has great potential for addressing concerns about academic preparedness in K-12 education and beyond, but that maximum benefit will arise when we carefully attend to developmental characteristics of preschoolers, cultural and linguistic diversity, ecosystemic context, and new mandates on teacher training.

\section{Why Universal Preschool?}

Advocates for publically funded, universal, voluntary preschool argue that such programs provide academic, social/ emotional, and economic benefits (National Institute for Education Research 2007). For example, Edward Zigler 
and colleagues have argued that an investment in early childhood education for all children provides not only the school readiness skills for academic learning, but also a critical foundation in social and emotional regulation that makes learning possible (Zigler et al. 2006). According to Karoly and Bigelow (2005), the direct and indirect returns on such an investment, as measured by job growth, crime prevention, and decreased reliance on social welfare programs has been estimated to be substantial (for every dollar invested yields a return of \$2.62). So if universal preschool has so much to offer, why have we not made the commitment?

Public opposition to universal preschool has been substantial. A California ballot initiative for universal preschool, advanced by actor/director Rob Reiner, was defeated in 2006 by a large margin. Critics argued that the alleged benefits of universal preschool would not materialize, and that the proposed tax increase to fund the program would both discourage investment in the state and drive wealthy families from California (Institute of Governmental Studies, University of California 2006). We wish to leave the economic forecasting to those more qualified to do so and focus our attention on key factors that could enhance the outcomes of universal preschool.

\section{Attention to Developmental Characteristics of Learners}

Recognizing and applying the unique developmental needs of preschoolers to early childhood education elevates programming from mere "day-care" to meaningful, enriching educational opportunities. Children three to four years of age are not simply smaller versions of their 5th grade counterparts. The cognitive and social/emotional developmental needs of early childhood learners demand specialized goals, objectives, and methods.

Proponents of publicly funded preschool wisely note that school readiness (i.e., preparedness for kindergarten) is a primary benefit of universal early childhood education. However, rarely is "readiness" operationalized. When some speak of readiness, the term is conceptualized as preliteracy and numeracy skills necessary for the efficient absorption of the elementary school curriculum. But this narrow view is an iteration of the four-year-old-as-smallfifth-grader perspective. Developmentally appropriate early childhood education's goals are to establish the foundation for a lifelong love of learning and optimal social/emotional development, for these are the precursors to successful learning in K-12 settings.

What methods, strategies, and techniques should preschool programs use to achieve the dual goals of fostering a love of learning and enhancing social/emotional development? Simply stated, the focus of early childhood education should be age-appropriate, nurturing, play-based instruction. Good early childhood educators are already doing this, and with phenomenal results. They recognize that socially and cognitively, the three and four-year-old crowd learns by playing and is supported in their social/ emotional development through encouragement, gentle limit setting, and unconditional positive regard.

Ultimately, school readiness comes not from an emphasis on academic preparedness in a conventional sense, but in preparing the hearts and minds of young children for participating in a community of learners. Listening, taking turns, respecting others, and student engagement in learning constitute the long-lasting benefits of age-appropriate goals and activities in preschool.

\section{Addressing Cultural and Linguistic Diversity}

Just as educators must attend to the unique developmental needs of early childhood learners, so must we take cultural and linguistic diversity into consideration, for the risks of ignoring diversity are significant (Sullivan and A'Vant 2009). Others have detailed the changing demographics of the United States, so we focus our energy on the implications rather than the statistical trends. Here we consider the importance of making the early childhood education experience both culturally relevant and practical for culturally and linguistically diverse young children.

Keeping the goals of universal preschool in focus allows us to see culturally responsive early childhood education as not merely a worthy end in itself, but as a means to achieving the readiness goals described above. Preschool children entering the school system experience a tremendous shift from the home and neighborhood as primary environments to the new world of school. Consequently, a culturally relevant curriculum facilitates the transition to school and nurtures the young learner. Moreover, inclusion of cultural diversity in early childhood education promotes respect for others and establishes the school as both familiar and accepting, laying the foundation for future learning.

The early childhood brain is primed for language development and schools are language-intense environments, which is to say that the vast majority of learning in schools is transmitted through spoken and printed language. That being the case, it stands to reason that at least in the preschool years, non-English speakers would stand to benefit from instruction in both their native language and in English, and that native English speakers would benefit from learning a second language. We reject an Englishonly approach because developmentally, early childhood learners need to feel comfortable in their learning environments, and instruction in their native language is a 
critical component of establishing such comfort. We now turn our attention to the provision of universal preschool in an ecosystemic framework.

\section{Incorporating an Ecosystemic Context}

Child development is best understood in an ecosystemic context that recognizes the environmental influences on the child (Bronfenbrenner 2004. Family, school, community, and larger systems play unique and important roles in human development. Moreover, the activity across these systems (e.g., collaboration across home and school systems) is significant. A large body of research has supported the notion that parent involvement is related to better educational outcomes (e.g., Christenson and Sheridan 2001). Here we promote an ecosystemic approach as a way of facilitating shared goals and responsibilities for schools and families by situating preschool not as a distinct, standalone institution, but rather as part of the child's network of critical systems.

Preschool programs that recognize families as partners in education are aware that most families want to participate in their children's education, and collaborative efforts pay off. Schools are a site of learning, but not the only site. Much learning occurs in homes and communities, and children learn best when there are consistent expectations across settings. In this respect, universal preschool enhances not only child readiness, but also family readiness for learning through high school and beyond.

We acknowledge considerable overlap between our promotion of both an ecosystemic framework and culturally responsive preschool programs, as schools will more easily partner with diverse families when they are aware of and respectful of families' beliefs, values, and traditions. But we emphasize that independent of culture and language, families want their children to be successful in school, and our efforts to include families in preschool education will go far in preventing academic failure and promoting sustained learning.

\section{Teacher Preparation for Universal Preschool}

High quality, universal preschool will require high quality teachers. Frost (2007) tells us that a "perfect storm" is mounting in the early childhood field, characterized by a more business-like approach to education with a focus on accountability that deemphasizes the role of play, discovery, and spontaneity; therefore, the preparation of new preschool teachers must emphasize developmentally appropriate programs and practices in order to foster young children's success. It is essential for teachers to be caring and culturally responsive to children in addition to helping them become academically prepared (Noddings 2006). Becoming familiar with cultural and social practices needs to be at the heart of the twenty-first century preschool teacher. Providing universal preschool education will prepare for our children's future success in a more global environment. Thus, the question becomes, "What attributes and skills should be nurtured for the children who today represent what our future is to become?"

Pink (2006), in his book, A Whole New Mind focuses on how we need to revisit teaching "as we have been taught" in light of looking at how the world and workplace will be different for the children of the twenty-first century. He states that children who are empathetic and creative thinkers capable of seeing patterns and the bigger picture will be more likely to succeed in a rapidly changing world. Therefore, teacher training must emphasize the importance of developing not only the cognitive skills, but also the social/emotional skills of the young learner.

Hirsh-Pasek et al. (2008) believe that the role of preschools in preparing children for readiness in mainstream education is becoming increasingly important. As teachers and administrators plan for curriculum and instruction, they need to rethink the traditional parameters of training-a reminder that children who will be the workforce of the future are today in our preschools (Temple University 2009). Hirsh-Pasek and Golinkoff (2009) argue that attributes necessary for the twenty-first century will be what they call the six C's: collaboration, communication, content, critical thinking, creative innovation, and confidence. Pre-service teachers need to learn about these qualities in their classes and ensure they are more universally addressed in programs for young children, adapting them into their plans for curriculum and instruction. Next, we outline how the six Cs (Hirsh-Pasek and Golinkoff 2009) readily translate to what would be appropriate for a universal preschool curriculum designed with twenty-first century skills.

Collaboration suggests a cooperative social environment. We must learn to work together locally as well as globally, embrace the ideas of others, and freely share our thoughts and expertise. The synergy that is created from collaboration is greater than what an individual or single group can produce. Teachers and administrators as well as children and the greater community, need to be given opportunities to work together and exchange information and views. We need to capitalize on our skills and strengths and use them to their greatest advantage. Opportunities for initiating collaborative activity abound in preschool and provide children with team building skills that will benefit them throughout their life. Educators need to focus on their collaborative efforts to bring together skills and ideas that will best address common goals. 
Communication is critical for success in the twenty-first century as our sense of community expands into more a web of more global networking. We need to be respectful of cultural differences and yet seek common ground to ensure understanding. Understanding what others are saying and being a good listener are valuable as is being a persuasive speaker. Many of our children come to school with limited language ability. Cultural and socio-economic differences make it essential for children to learn early the patience and understanding necessary to interact with others. Universal preschools would afford more of our young children an opportunity to learn these valuable skills early. Their daily interactions would boost their ability to work in environments of diversity.

When we refer to content, most people would list math, literacy, and language skills because traditionally they have been most valued in American education. Our technical, information society is bombarding our students with ideas, some of which are intellectually stimulating and some of which is inappropriate; for those lacking access we are creating an intellectual divide. We need to rethink the content in broader context so that children have experiences that enrich and expand their learning. Opportunities to experience the arts and social sciences in ways that promote creative expression, develop curiosity, and foster inquiry will be valuable in twenty-first century arenas. However, poverty, isolation and accessibility, cultural barriers as well as other factors, create great division in exposure to important life events and information that, if not addressed early, can extend well into the upper grades and later undermine the success of future families, the work force, the economy, and ultimately, the government.

Fourth is critical thinking. To be successful in the twenty-first century, we must be able to employ purposeful judgment to understand, process, and use the information presented to us. To interface with the people and situations of our environment we need skills, abilities, and experiences that enable us to ask pertinent and leading questions, consider possibilities, and integrate information so that it is connected and appropriate for accomplishing our goals. We need to become reflective practitioners so that we are more cognizant of the "what and why" of our success and may benefit from our actions in the future.

Fifth is creative innovation. Emerging teachers are drilled in content, the what to teach, but sometimes lack the repertoire of skills to allow children variety in how they address their personal learning and interact with their environment. We need to find ways to nurture inventiveness so that our children seek to know more and to find better ways of doing things, thus becoming innovative architects of our future. Opportunities to experiment and use and do things in developmentally appropriate, non- traditional ways will encourage children to think divergently, from conceptualization to implementation.

Sixth is confidence. Children need early social experiences to learn how to interact with people and their environment. They build upon prior experience and gain selfassuredness from a sense of what comes next and what works best. Ironically, curriculum and teachers can thwart learning and erode confidence. According to Hirsh-Pasek and Golinkoff (2009), "We're so busy being cautious that we're not giving our kids a chance to fail at anything." Confident children become confident adults who are risk takers.

We need to rethink edutainment, gimmicks, and standardization. What is it that we want our children to know and be able to do to be successful in the future, and how can we best provide an environment that nurtures those skills and attributes? Teacher training institutions and schools have an important role in helping emerging and practicing teachers to rethink both curriculum and instruction to ensure developmental appropriateness for today and the applicability to jobs and the world of tomorrow.

The National Commission on Teaching and America's Future (2006), advocates for how we can improve our schools and provide every child in America with twentyfirst century teaching. Strategies for improvement include creating strong learning teams in schools; closing the gap between teacher preparation and practice; supporting professionally rewarding teaching careers; and developing authentic teaching standards and learning assessments. The emphasis on collaborative learning teams and appropriate learning environments are clearly important for twenty-first century education (Carroll 2009).

\section{Conclusion}

In short, universal preschool requires a unique model of teacher preparation, curricular goals, and instructional methods. There is little doubt that success in universal preschools, like any other educational setting, depends on sensitivity to diverse learners. Universal public preschool presents an opportunity to welcome new learners to public education in such a way that values their unique contributions to the learning community. Moreover, school and community need not be separated by a vast chasm; there's great potential for community-school partnering. A recognition and appreciation of cultural and linguistic learners will enhance education at the preschool level and beyond.

To prepare the best educators for our youngest students, we promote high quality early childhood education for all. A far cry from the intense focus on basic academic skills, this approach prepares teachers to develop students that are 
learners in the broadest sense. This is so critical because early childhood education lays the foundation for lifelong learning. We acknowledge that universal preschool will be costly, but we believe that not providing high quality, developmentally appropriate, culturally-sensitive preschool from high quality teachers will be even costlier.

\section{References}

Bronfenbrenner, U. (2004). Making beings human: bioecological perspectives on human development. Thousand Oaks, CA: Sage.

Carroll, T. (2009). The next generation of learning teams. Phi Delta Kappan, 91, 8-13.

Christenson, S. L., \& Sheridan, S. M. (2001). Schools and families: Creating essential tools for learning. New York, NY: Guilford.

Frost, J. L. (2007). The changing culture of childhood: A perfect storm. Childhood Education, 83, 225-230.

Hirsch-Pasek, K., Golinkoff, R. M., Berk, L. E., \& Singer, D. (2008). A mandate for playful learning in preschool: Presenting the evidence. New York, NY: Oxford University Press.

Hirsh-Pasek, K., \& Golinkoff, R. M. (2009). Playing for the future: The 6 C's. Invited address at the association of children's museum conference, Philadelphia, PA, May.

Institute of Governmental Studies, University of California. (2006). Proposition 82: Universal preschool. Retrieved April 26, 2010, from University of California, Berkeley, Institute of Governmental Studies web site: http://igs.berkeley.edu/library/htUniver salPreschool.html\#Topic3.
Karoly, L. A., \& Bigelow, J. H. (2005). The economics of investing in universal preschool education in California. Santa Monica, CA: Rand Corporation.

National Commission on Teaching and America's Future. (2006). NCTAF research reports. Retrieved April 26, 2010, from http:// www.nctaf.org/resources/research_and_reports/nctaf_research_ reports/index.htm.

National Institute for Early Education Research. (2007). The universal vs. targeted debate: Should the United States have preschool for all? Retrieved April 26, 2010, from http://nieer. org/resources/factsheets/6.pdf.

Noddings, N. (2006). Teaching themes of care. Phi Delta Kappan, 76, 675-679.

Pink, D. (2006). A whole new mind: Why right-brainers will rule the future. New York, NY: Penguin Group.

Simmons, D. (2011). U.S. education still found lax in science, math. The Washington Times. Retrieved from http://www.washington times.com/news/2011/jan/25/us-students-still-lag-science-math/.

Sullivan, A. L., \& A'Vant, E. (2009). On the need for cultural responsiveness. NASP Communique, 38. Retrieved April 26, 2010, from http://www.nasponline.org/publications/cq/mocq383 culturalresponsive.aspx.

Temple University. (2009). For pre-school, it's not the ABCs, but the five Cs. Retrieved April 26, 2010, from Temple University, Temple Cutting Edge web site: http://templecuttingedge.word press.com/2009/08/14/for-pre-school-its-nottheabcsbutthefivecs.

Zigler, E., Gilliam, W. S., \& Jones, S. M. (2006). A vision for universal preschool education. New York, NY: Cambridge University Press. 